Iranian Journal of Pathology | ISSN: 2345-3656

\title{
MIF and MMP-9 Serum Changes in Type II Diabetes and Non-Diabetic Subjects: A Short Communication
}

\author{
Alireza Rastgoo Haghi ${ }^{1 *}$, Nasrin Khorami ${ }^{2}$, Mahtab Fotoohi ${ }^{1}$, Abbas Moradi ${ }^{3}$ \\ 1. Department of Pathology, School of Medicine, Hamadan University of Medical Sciences, Hamadan, Iran \\ 2. Department of Internal Medicine-Endocrinology, School of Medicine, Hamadan University of Medical Sciences, Hamadan, Iran \\ 3. Department of Community Medicine. Hamedan University of Medical science. Iran
}

\begin{tabular}{c}
\hline KEYWORDS \\
Diabetes Type 2, HbA1C, \\
MIF, MMP-9 \\
Scan to discover online \\
D. \\
Main Subjects: \\
Molecular Pathology \\
Received 05 May 2020; \\
Accepted 29 Jun 2021; \\
Published Online 06 Jul 2021; \\
\hline
\end{tabular}

$\underline{\text { 10.30699/IJP.2021.131429.2456 }}$

\section{ABSTRACT}

Background \& Objective: Diabetes is a metabolic disease and is associated with failure of various organs. Macrophage migration factor (MIF) and matrix metalloproteinase (MMP-9) are two of the most important factors in the pathogenesis of diabetes.

\begin{abstract}
Methods: In this descriptive-analytical study, 30 patients with type 2 diabetes mellitus from Hamadan Diabetes Center were selected by convenience sampling. Moreover, 30 healthy firstdegree relatives and 30 unrelated non-diabetics, were examined for MMF and MMP-9 and their variations based on age, gender, body mass index (BMI) and hemoglobin A1C.

Results \& Conclusion: The mean and standard deviation of MIF in diabetic patients, and relatives and non-relatives of diabetic patients were $592.87 \pm 78.19,131.82 \pm 88.27$ and $94.63 \pm 23.88$, respectively $(P<0.001)$. The mean and standard deviation of the MMP-9 in diabetic patients, and relatives and non-relatives of diabetic patients were $2570.64 \pm 2220.03,918.57 \pm 650.08$ and $629.09 \pm 288.32$, respectively $(P<0.001)$. MIF and MMP-9 did not have a significant relationship with age, sex, duration of disease and BMI. However, we observed a direct and significant correlation between hemoglobin A1C and the level of MIF and MMP-9 $(P<0.001)$. In patients with type 2 diabetes, serum levels of MMP-9 and MIF, consistent with HbAlc, increase with no significant association with age, sex, BMI and duration of diabetes.
\end{abstract}

Corresponding Information:

Alireza Rastgoo Haghi, Department of Pathology, School of Medicine, Hamadan University of Medical Sciences, Hamadan, Iran E-mail: moba.kte@gmail.com

Copyright (C) 2021. This is an open-access article distributed under the terms of the Creative Commons Attribution- 4.0 International License which permits Share, copy and redistribution of the material in any medium or format or adapt, remix, transform, and build upon the material for any purpose, even commercially.

\section{Introduction}

Diabetes mellitus is a metabolic and multifactorial disease characterized by hyperglycemia, and accompanied by various organ failures $(1,2)$. Studies on inflammatory cytokines that cause diabetes are of great importance. Macrophage migration factor (MIF) and matrix metalloproteinase (MMP-9) are the most important factors in the pathogenesis of diabetes $(3,4)$. MIF affects the expression of Toll-like receptor (TLR4) on antigen presenting cells, preserving the ability of macrophage to interfere with P53 inhibition and has tautomerase and oxidoreductase activity (5-7). Studies on the animal models have shown that inhibition of MIF as a therapeutic approach. Another group of factors affecting the pathogenesis of diabetes and the associated complications are MMPs (8). Hyperglycemic conditions increase the expression of MMP1, MMP-2 and MMP-9 genes and increase their activity in endothelial cells and macrophages (9-11). The present study evaluates the levels of MIF and MMP-9 in non-diabetics in the families with family members who have type 2 diabetes mellitus. This provides promising evidence.

\section{Material and Methods}

In this study, 30 patients with type 2 diabetes, 30 non-diabetics selected from first-degree relatives of patients with diabetes and 30 unrelated non-diabetics as control group were selected. All subjects were interviewed and serum samples were prepared for Fasting Blood sugar (FBS) and HbA1c tests, and were approved according to the previous medical histories and the results of the healthy group. Diabetics were categorized based on $\mathrm{HbAlc}$ level into optimal control group $(\mathrm{HbA} 1 \mathrm{c}<7)$ and undesirable control group (HbA1c>7). MMP-9 and MIF levels were measured by direct sandwich ELISA (East biopharm Company kit) according to the manufacturer's instructions as follows: $40 \mu \mathrm{L}$ of the sample was mixed with $10 \mu \mathrm{L}$ of MMP-9 and MIF antibodies and $50 \mu \mathrm{L}$ of Streptavidin-HRP. Then, the lid was tightly closed. The plate was shaken 
slowly and incubated at $37^{\circ} \mathrm{C}$ for 60 minutes. The sample was then diluted 30 times and washed with water. Subsequently, we added $50 \mu \mathrm{L}$ of colored solution $\mathrm{A}$ and $\mathrm{B}$ to each of the wells. We slowly mixed and incubated the plate for 10 minutes at $37^{\circ} \mathrm{C}$. Then, $50 \mu \mathrm{L}$ of stop solution was added to each of the wells to stop the reaction. At this point, the color quickly changed from blue to yellow. The device was zeroed at 450 nanometers $(\mathrm{nm})$ at a wavelength of $450 \mathrm{~nm}$ and the sample standard OD was accurately measured and then, the final concentration of the sample was obtained. The measurement range of the test kit for testing MIF was between 10-30 ng/mL. The sensitivity of the kit was $54.6 \mathrm{ng} / \mathrm{mL}$, and for MMP-9 in the range of $30-35 \mathrm{ng} / \mathrm{mL}$, with a sensitivity of $15.12 \mathrm{ng} / \mathrm{L}$.

\section{Results \& Discussion}

Based on Kruskal-Wallis test and Tukey's post hoc test, there was a significant difference in the mean level of macrophage migration inhibitor in type 2 diabetic patients and non-familial control group $(P<0.05)$. However, the difference between the mean levels of the inhibitory factor of macrophage migration in the control group was not statistically significant (Table 1). Also, based on Kruskal-Wallis non-parametric test and
Tukey's post hoc test, the mean level of MMP-9 in type 2 diabetic patients was significantly more than familial and non-familial control groups $(P<0.05)$. However, the difference between the mean level of MMP-9 in the familial and non-familial control group was not statistically significant (Table 1). Moreover, there was no statistically significant difference between the male and female sexes in terms of the mean level of inhibitory factor of macrophage migration and also the MMP-9 level (Table 2). Results of the Pearson correlation test showed a reverse correlation between age and level of macrophage migration inhibitor $(\mathrm{r}=$ $0.218, P=0.247)$ and MMP-9 $(\mathrm{r}=-0.279, P=0.136)$, but it was not statistically significant. There was a direct and significant correlation between hemoglobin A1c and the level of macrophage migration inhibitor $(\mathrm{r}=0.821, P<0.001)$ and MMP-9 $(\mathrm{r}=0.745, P<0.001)$. There was no significant correlation between the duration of type 2 diabetes mellitus and the level of macrophage migration inhibitor $(\mathrm{r}=0.165, P=0.385)$ and MMP-9 $(\mathrm{r}=0.196, P=0.299)$. There was no significant correlation between BMI and Type 2 diabetes mellitus with macrophage migration inhibitor $(\mathrm{r}=-0.242, P=0.197)$ and MMP-9 $(\mathrm{r}=-0.262, P=0.163)$. By increasing the hemoglobin $\mathrm{A} 1 \mathrm{C}$, the mean MIF and MMP-9 also increased significantly (Table 3 ).

Table 1. Mean of factor levels in different study groups

\begin{tabular}{|c|c|c|c|c|}
\hline \multicolumn{1}{|c|}{ Groups } & First degree family & non-relatives & P-value \\
\hline $\begin{array}{c}\text { Factor levels } \\
\text { Mean } \pm \text { SD) }\end{array}$ & Diabetics & $131.82 \pm 88.27$ & $94.63 \pm 23.88$ & $<0.001$ \\
\hline MIF & $592.78 \pm 678.19$ & $918.57 \pm 650.08$ & $629.09 \pm 288.32$ & $<0.001$ \\
\hline MMP-9 & $2570.64 \pm 2220.03$ & & \\
\hline
\end{tabular}

Table 2. Mean of factor levels in different genders of the study

\begin{tabular}{|c|c|c|c|}
\hline \multirow{2}{*}{ Factor levels in different genders } & Mean \pm Standard Deviation & P-value* $^{*}$ \\
\cline { 2 - 4 } & Male & $712.42 \pm 754.21$ & 0.344 \\
\hline \multirow{2}{*}{ MMP-9 } & Female & $532.96 \pm 694.05$ & 0.379 \\
\cline { 2 - 4 } & Female & $2864.79 \pm 2377.45$ & \\
\hline
\end{tabular}

\footnotetext{
* Non-parametric Mann-Whitney test
}

In the present study, the mean MIF and MMP-9 level in type 2 diabetes mellitus patients was significantly higher than that of non-familial control group. However, there was no significant difference between the control group in diabetic families and the non-related control group in terms of MIF and MMP-9 levels. The results of Yuriko et al. showed that MIF is an effective polytropic molecule of pancreatic islets and pro-inflammatory cytokines that not only plays a role in diabetes, but also in the early stages of the disease and its risk factors such as obesity (12). In the study of Lee et al., The results showed that MMP-9 plasma levels were significantly lower in diabetic patients than in control group (13). Similarly, these results repeated in the study of Lewandowski et al.. There was a reverse correlation between BMI and MMP-9 levels, and there was a positive correlation between HbAlc and MMP-9 levels (14). Comparing metalloproteinase 2 and 9 and tissue inhibitors in diabetic and non-diabetic patients, Derosa et al. 
Table 3. Comparison between the factor levels and the different levels of $\mathrm{HbAlc}$

\begin{tabular}{|c|c|c|c|c|c|c|}
\hline \multirow{2}{*}{\multicolumn{2}{|c|}{$\begin{array}{c}\text { Factors } \\
\text { and } \\
\text { HbA1c levels }\end{array}$}} & \multirow[b]{2}{*}{$\mathbf{N}$} & \multirow[b]{2}{*}{ Mean \pm SD } & \multicolumn{2}{|c|}{$95 \% \mathrm{CI}$} & \multirow[b]{2}{*}{ P-value } \\
\hline & & & & $\begin{array}{l}\text { Upper } \\
\text { Bound }\end{array}$ & $\begin{array}{l}\text { Lower } \\
\text { Bound }\end{array}$ & \\
\hline \multirow{4}{*}{ MIF } & 4.2-6.9 & 75 & $136.364 \pm 98.277$ & 158.9766 & 113.7533 & \multirow{4}{*}{$<0.001$} \\
\hline & $7-8.9$ & 12 & $677.529 \pm 530.514$ & 1014.6021 & 340.4562 & \\
\hline & $9 \leq$ & 3 & $2073.100 \pm 807.904$ & 4080.0456 & 66.1544 & \\
\hline & total & 90 & $273.078 \pm 452.223$ & 367.7944 & 178.3616 & \\
\hline \multirow{4}{*}{ MMP-9 } & 4.2-6.9 & 75 & $877.485 \pm 638.029$ & 1024.2830 & 730.6885 & \multirow{4}{*}{$<0.001$} \\
\hline & $7-8.9$ & 12 & $3095.390 \pm 1831.426$ & 4259.0239 & 1931.7577 & \\
\hline & $9 \leq$ & 3 & $6864.200 \pm 2440.418$ & 12926.5358 & 801.8642 & \\
\hline & total & 90 & $1372.763 \pm 1584.351$ & 1040.9275 & 1584.35172 & \\
\hline
\end{tabular}

showed that MMP-9 plasma levels were significantly higher in patients with diabetes than in healthy subjects (15). Moreover, in a study conducted in India regarding MMP in type 2 diabetic patients, the results showed that MMP levels in type 2 diabetic patients increased significantly (8). The results of this study were consistent with the studies of Lewandowski, Derosa and Das et al. in terms of the increase in serum MMP levels in diabetic patients. Our results were inconsistent with the results of Lee et al. (13-15). In the present study, there was no significant difference between gender and the mean level of macrophage migration inhibitor and MMP-9 in type 2 diabetes. There was a significant and direct correlation between age, BMI, duration of disease and hemoglobin A1C and macrophage migration inhibitor and MMP-9 levels. However, only the correlation between hemoglobin $\mathrm{A} 1 \mathrm{C}$ and the level of macrophage migration and MMP9 inhibitor was statistically significant. In the study of Lewandowski et al., there was a reverse correlation between BMI and MMP-9 levels, and a positive correlation between hemoglobin A1c and MMP-9 level (14). These results were similar to our study findings. Considering that in diabetic patients, MMP-9 and MIF levels are elevated, and are directly related to hemoglobin A1c levels, it is suggested to use both of these factors to measure the presence of diabetes, based on the existing conditions and possibilities. It is suggested that in an analytical study, the role of MMP9 and MIF factors in the incidence of diabetes complications should be investigated. In order to increase the reliability of the study, it is recommended to repeat the study in a multicenter study with a larger sample size.

\section{Conclusion}

In diabetics, MMP-9 and MIF levels were consistent with the level of hemoglobin A1C, but there was no significant increase in MMP-9 and MIF in firstdegree relatives of diabetic and normal people. Since these factors did not significantly increase in diabetics and their normal relatives, they cannot be used as predictors of diabetes.

\section{Acknowledgements}

None.

\section{Conflict of Interest}

None.

\section{References}

1. American Diabetes Association, Diagnosis and classification of diabetes mellitus. Diabetes Care, 2010; 33(1):S62-S69. [DOI:10.2337/dc10-S062]

2. David JR. Delayed hypersensitivity in vitro: its mediation by cell-free substances formed by lymphoid cell-antigen interaction. Proc Natl Acad Sci U S A. 1966;56(1):72-7. [DOI:10.1073/pnas.56.1.72]
3. Cavallo GP, Landolfo S. Biological aspects of the macrophage migration inhibition factor (MIF). G Batteriol Virol Immunol. 1980;73(7-12):196.

4. Malorny U, Goebeler M, Gutwald J, Roth J, Sorg C. Differences in migration inhibitory factor production by $\mathrm{C} 57 \mathrm{~B} 1 / 6$ and $\mathrm{BALB} / \mathrm{c}$ mice in allergic and irritant contact dermatitis. Int Arch 
Allergy Appl Immunol. 1990;92(4):356-60. [DOI:10.1159/000235164]

5. de Jong YP, Abadia-Molina AC, Satoskar AR, Clarke K, Rietdijk ST, Faubion WA, Emiko Mizoguchi CN, Al SahlF M, ten Hove T, Keates AC, Lubetskv JB. Development of chronic colitis is dependent on the cytokine MIF. Nat Immunol 2002 Apr;3(4):407.

6. Abe R, Shimizu T, Ohkawara A, Nishihira J. Enhancement of macrophage migration inhibitory factor (MIF) expression in injured epidermis and cultured fibroblasts. Biochim Biophys Acta. 2000;1500(1):1-9. [DOI:10.1016/S0925-4439(99)00080-0]

7. Roger T, Froidevaux C, Martin C, Calandra T. Macrophage migration inhibitory factor (MIF) regulates host responses to endotoxin through modulation of Toll-like receptor 4 (TLR4). J Endotoxin Res. 2003;9(2):119-23. [DOI:10.1177/09680519030090020801]

8. Sugimoto H, Taniguchi M, Nakagawa A, Tanaka I, Suzuki M, Nishihira J. Crystal structure of human D-dopachrome tautomerase, a homologue of macrophage migration inhibitory factor, at 1.54 $\AA$ resolution. Biochemistry. 1999;38(11):326879. [DOI:10.1021/bi982184o]

9. Terrazas CA, Juarez I, Terrazas LI, Saavedra R, Calleja EA, Rodriguez-Sosa M. Toxoplasma gondii: impaired maturation and proinflammatory response of dendritic cells in MIFdeficient mice favors susceptibility to infection. Exp Parasitol. 2010;126(3):348-58. [DOI:10.1016/i.exppara.2010.03.009]

10. Hoi AY, Iskander MN, Morand EF. Macrophage migration inhibitory factor: a therapeutic target across inflammatory diseases. Inflamm Allergy Drug Targets. 2007;6(3):183-90. [DOI:10.2174/187152807781696455]

11. Mitchell RA, Liao H, Chesney J, FingerleRowson G, Baugh J, David J, Bucala R. Macrophage migration inhibitory factor (MIF) sustains macrophage proinflammatory function by inhibiting p53: regulatory role in the innate immune response. Proc Nat Acad Sci. 2002;99(1):345-50.

[DOI:10.1073/pnas.012511599]

12. Yuriko I. Sánchez-Zamora and Miriam Rodriguez-Sosa. The Role of MIF in Type 1 and Type 2 Diabetes Mellitus. J Diabetes Res. 2014; 2014: 804519. [DOI:10.1155/2014/804519]

13. Lee SW, Song KE, Shin DS, Ahn SM, Ha ES, Kim DJ, Nam MS, Lee KW. Alterations in peripheral blood levels of TIMP-1, MMP-2, and MMP-9 in patients with type-2 diabetes. Diabetes Res Clin Pract 2005; 69(2):175-9. [DOI:10.1016/j.diabres.2004.12.010]

14. Lewandowski KC, Banach E, Bieńkiewicz M, Lewiński A. Matrix metalloproteinases in type 2 diabetes and non-diabetic controls: effects of short-term and chronic hyperglycaemia. Arch Med Sci: AMS. 2011;7(2):294. [DOI:10.5114/aoms.2011.22081]

15. Derosa G, D'angelo A, Tinelli C, Devangelio E, Consoli A, Miccoli R, Penno G, Del Prato S, Paniga S, Cicero AF. Evaluation of metalloproteinase 2 and 9 levels and their inhibitors in diabetic and healthy subjects. Diabetes Metab. 2007;33(2):129-34. [DOI:10.1016/j.diabet.2006.11.008]

\section{How to Cite This Article}

Rastgoo Haghi, A., Khorami, N., Fotoohi, M., Moradi, A MIF and MMP-9 Serum Changes in Type II Diabetes and Non-Diabetic Subjects. Iran J Pathol, 2021; 16(4): 444-447. doi: 10.30699/IJP.2021.131429.2456 